\title{
Working
}

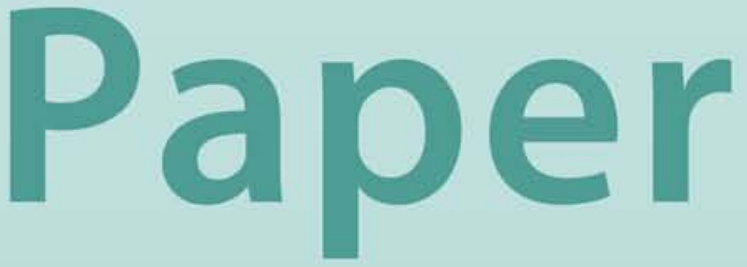




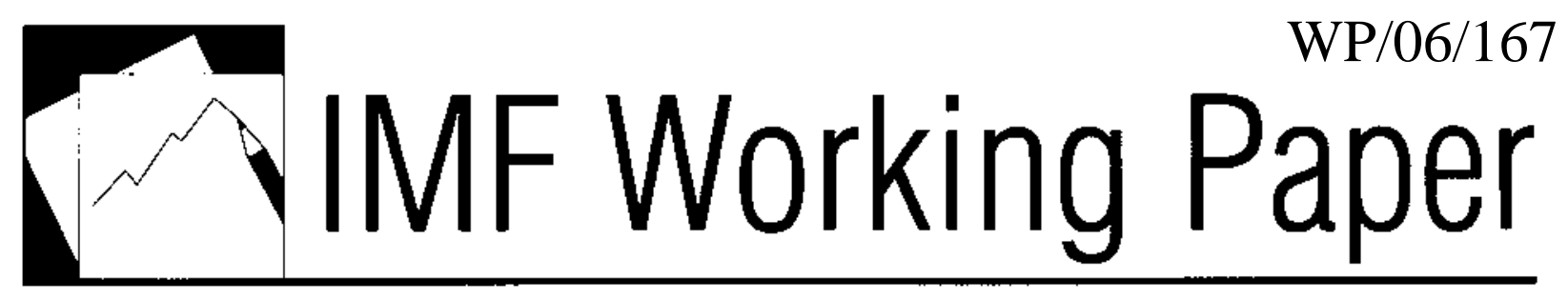

Ukraine: The Cost of Weak Institutions

Andrew Tiffin 


\title{
IMF Working Paper
}

European Department

\section{Ukraine: The Cost of Weak Institutions}

\section{Prepared by Andrew Tiffin}

Authorized for distribution by Emmanuel van der Mensbrugghe

July 2006

\begin{abstract}

\section{This Working Paper should not be reported as representing the views of the IMF.}

The views expressed in this Working Paper are those of the author(s) and do not necessarily represent those of the IMF or IMF policy. Working Papers describe research in progress by the author(s) and are published to elicit comments and to further debate.

Ukraine has the potential to be a very wealthy country. It has a well-educated workforce, some of the best agricultural land in the world, an enviable supply of hydrocarbons and minerals, and a relatively well-developed infrastructure. Despite these advantages, however, Ukraine's per capita income remains low. Using a cross-country stochastic-frontier framework, this paper argues that Ukraine's failure to tap its full potential is mainly a result of its market-unfriendly institutional base. With an inherited Soviet framework that is ill suited to the needs of a market economy, Ukraine has been slow to establish the institutions needed to use its resources efficiently. The paper provides a quantitative guide to the benefits, in terms of potential output, of further structural reform. Looking forward, the study finds that durable growth in Ukraine will depend primarily on the authorities' ability to implement their ambitious reform agenda, and thereby to help secure the basic foundations of a modern market economy.
\end{abstract}

JEL Classification Numbers: C23, O33, O47, P27

Keywords: Total factor productivity, stochastic frontiers, technical efficiency, institutions, transition economies

Author(s) E-Mail Address: atiffin@imf.org 


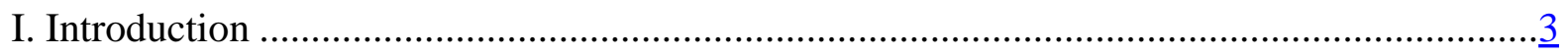

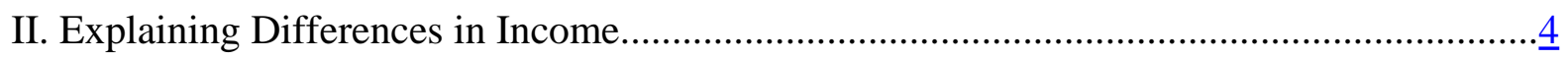

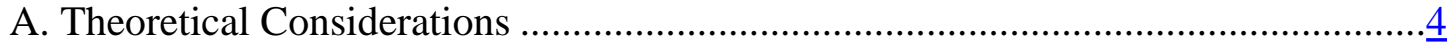

B. Previous Literature ………………………………………………………....

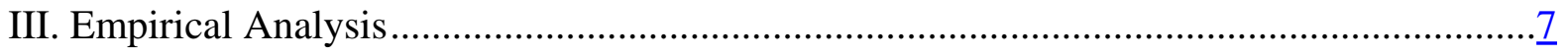

A. The Model ...............................................................................................

B. Econometric Considerations …………………………....................................

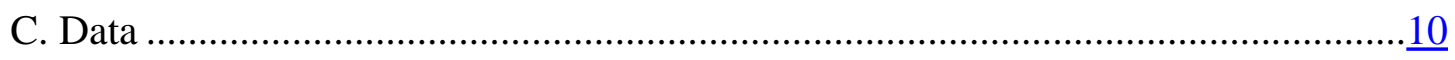

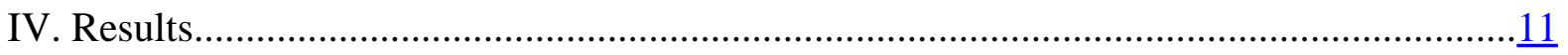

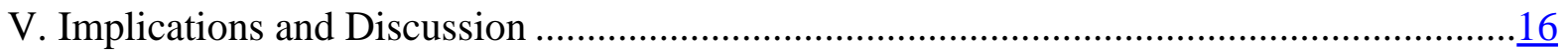

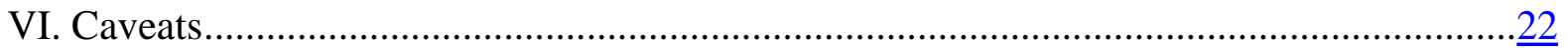

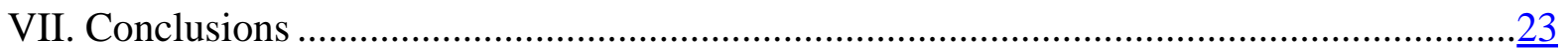

Tables

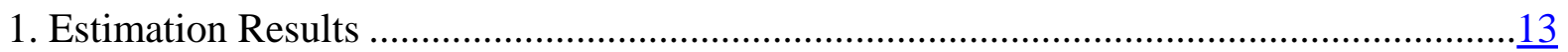

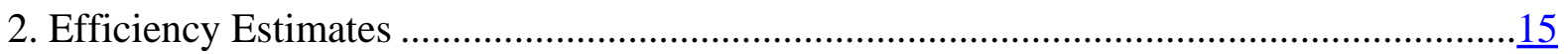

3. Contributions to Long-Term Growth, 2005-15 ..............................................................

4. Key Aspects of the Ukraine-EU Action Plan ....................................................................

Figures

1. The Global Best-Practice Frontier ………………….......................................................15

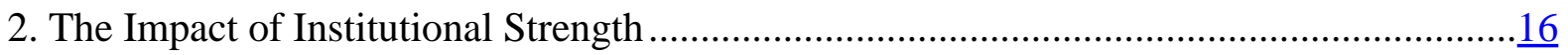

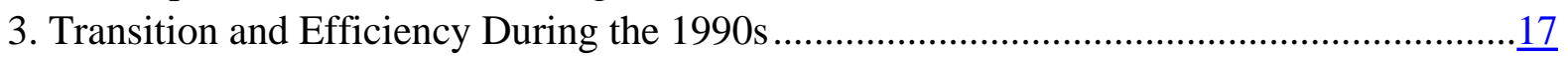

4. Ukraine: Alternative Scenarios ....................................................................................

Appendix

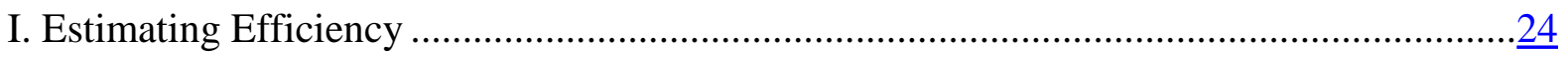

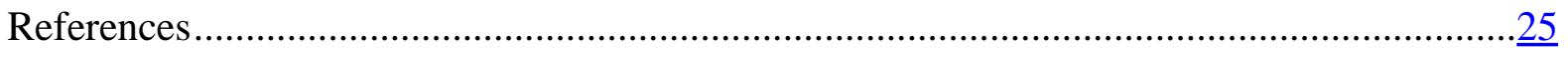


"I represent one of the largest European nations. It is a nation with an educated population, a market size of 50 million people and is situated at the geographical heart of Europe. My country has long been a wise and strong, but sleeping elephant. Today it is awakening to its potential...."

President Viktor Yushchenko, 28 January 2005

"How do we account for poverty in the midst of plenty? We must create incentives for people to invest in more efficient technology, increase their skills, and organize efficient markets. Such incentives are embodied in institutions."

Douglass North

\section{INTRODUCTION}

Following the dramatic political events of 2004, the incoming Yushchenko administration moved quickly to articulate its new policy goals. Yushchenko presented a broad vision that extended beyond simple macroeconomic stabilization, focusing instead on accelerating Ukraine's transition toward a modern market economy. Much of this agenda is anchored within a medium-term strategy of greater integration with the European Union (EU) and global markets, and has been expressed operationally in documents such as the Ukraine-EU Action Plan and the recent Development Policy Loan with the World Bank. According to this vision, development of more market-friendly institutions will help ensure that Ukraine's impressive post-2000 recovery can be sustained over the medium term.

This paper investigates the economic importance of institutions in Ukraine and attempts to quantify the potential benefits of market-friendly structural reform. It addresses two questions. To what extent have market-unfriendly institutions hampered economic performance in the past? And what would be the likely payoff in terms of higher growth and living standards if the authorities succeed in their medium-term objective of strengthening market-enhancing reform?

Using a cross-country framework, the results suggest that Ukraine has an enviable endowment of natural and human resources, but that the economy has failed to use these resources efficiently. The results further find that this inefficiency stems from the marketunfriendly rules and practices that make up Ukraine's institutional base. Hypothetically, for example, if Ukraine were to possess the type of market-friendly institutions enjoyed by those countries that recently joined the EU, income per worker might almost double. This highlights the fact that achieving a high rate of sustainable growth in Ukraine will depend on much more than simply increasing the pace of investment-durable growth will depend instead on the authorities' ability to secure the basic foundations of a modern market economy. 
Section II of this paper reviews some of the key findings of the development-accounting literature, which has tried to explain the significant differences in income that persist across countries. The section also introduces the stochastic-frontier approach used in this paper, outlining its key assumptions and strengths. Section III presents the stochastic-frontier model in more detail, and Section IV outlines our results. Section V discusses the implications of these results specifically for Ukraine, quantifying the likely growth path for Ukraine over the next decade under different reform scenarios. Section VI briefly outlines some possible caveats and areas for further research, and Section VII concludes.

\section{EXPLAINING DIFFERENCES IN INCOME}

\section{A. Theoretical Considerations}

A key finding of the development-accounting literature is that international differences in income result mainly from differences in productivity, rather than factor accumulation. As outlined in Hall and Jones (1999), McGrattan and Schmitz (1998) and others, the income gap between rich and poor countries is vast and cannot be explained by differences in capital, labor, or other resources. Instead, the key determinant of an economy's relative income is its level of productivity.

The obvious follow-up issue, therefore, is how to account for such variations in productivity. Productivity disparities can be broken down into differences in: i) technology, representing the sum of available knowledge as to how factors of production can best be combined, and ii) efficiency, representing how effectively a country's factors are actually used in practice.

Given the rapid diffusion of knowledge across the globe, explanations that rely on technology gaps to account for large and persistent differences in productivity are generally implausible. To illustrate, we can consider the productivity difference between the United States and Ukraine-asking whether this can be explained in terms of efficiency, or whether it reflects instead the less-advanced technology available to Ukrainian producers. One way of tackling the question is by expressing the technology gap in terms of time, i.e., estimating how far Ukraine lags behind the United States. Using an estimate from Weil (2005), the average annual growth rate of U.S. productivity over 1960-2000 was 0.81 percent. Taking this growth rate, and assuming that the difference between the two countries is entirely the result of different technology-i.e., assuming that each country uses its resources optimally - the size of the productivity gap implies that Ukraine is over 200 years behind the United States. ${ }^{1}$ This is clearly unlikely. Similar calculations can be carried out for other

\footnotetext{
${ }^{1}$ With no differences in country-level efficiency, the productivity ratio between two countries can be expressed as $A_{U S A} / A_{U K R}=(1+g)^{T}$, where $g$ is the rate of technological change, and $T$ represents the length of time that would be required for the lagging country to catch up.
} 
developing and emerging countries, and all highlight the same message: unless lags in technology are extremely large, most of the productivity gap between rich and poor countries reflects differences in efficiency rather than technology.

It should be stressed here that "technology" refers to the sum of knowledge that is implicitly available to local producers. This is conceptually different from the technologies that are actually observed in the workplace. Even with equal ex ante access to an identical knowledge base, the range of technologies that are adopted ex post may vary across countries, depending on the circumstances of the country in question. Sometimes, this may simply reflect resource differences or comparative advantage. Often, however, it reflects country-specific frictions that prevent the profitable use of the most productive techniques. In this sense, the presence of obsolete techniques does not necessarily imply a technology/knowledge gap. Rather, it may reflect underlying structural weaknesses within an economy which discourage producers from adopting best-practice techniques, either because of burdensome regulations or because their economic environment is such that they cannot use these techniques efficiently. In this framework, therefore, the presence of suboptimal technologies may be a symptom of poor efficiency, rather than a result of unavailable technology.

The main challenge, therefore, is to explore the reasons behind international differences in efficiency.

Inefficiency may arise from various sources.

- $\quad$ Unproductive activities, such as theft, smuggling, or rent-seeking behavior. This might also include the production of unwanted goods resulting from political decision making and producer activity designed to prevent theft or expropriation (fences versus factories).

- $\quad$ Idle resources, reflecting not only unemployment from macroeconomic instability, but also underemployment associated with overstaffed state-run enterprises.

- Misallocation of factors across sectors, which may in turn reflect barriers to mobility, or situations in which factor prices are not equal to marginal productivity.

All of these sources of inefficiency have played a significant role in transition countries, often reflecting the legacy of communist central planning. Much of what the communist economies produced was of little or no value, and compared to general practice in the West, socialist industry often employed several times more inputs (especially energy) to produce the same volume of output.

Persistently low levels of efficiency result from an underlying absence of market-friendly institutions. The definition of "institutions" can vary, but in an economic context the concept generally refers to the set of formal and informal constraints and incentives that shape an 
individual's ability to act productively and cooperatively. Typically, a market-friendly institutional base will include such items as the rule of law, secure property rights, enforceable contracts, an evenhanded and transparent government, and so on. The absence of such institutions adversely impacts the population's willingness to engage in mutually beneficial trade or to seek more productive opportunities.

Theoretically, this point is relatively uncontroversial. For example, Parente and Prescott (2004), as part of a model that seeks to explain the historical path of income between countries and across time, highlight the crucial role of this link between institutions and efficiency. Their Theory of Relative Efficiencies stresses that governments have historically attempted to favor particular factor owners or interest groups by constraining the choice of technologies or work practices of their citizenry. Inter alia, such practices often take the form of arbitrary and unaccountable government intervention, with adverse results for overall efficiency. Similarly, Gonzalez (2005) uses a game theoretic framework to show that, in the absence of effective property rights, agents will often adopt a suboptimal technology in order to avoid predatory expropriation by others. He further shows that this outcome may prevail even in a situation where the adoption of efficient technology is costless.

To quantify the level of efficiency in Ukraine and other countries, we adopt a stochasticfrontier framework. This econometric technique dates back to Aigner, Lovell, and Schmidt (1977) and is specifically designed for situations in which agents operate less than optimally. In a production context, where it is most often employed, it typically uses cross-section data to estimate a best-practice frontier-i.e., what a firm or country could have produced if it were operating at 100 percent efficiency. The actual output of the country is then measured against this hypothetical benchmark as a guide to its overall level of efficiency.

In a cross-country context, this framework allows us to decompose each country's total factor productivity (TFP) into the product of two components: i) an efficiency component; and ii) a technology component. The technology component is common across countries, as all countries are assumed to have equal access to the current stock of productive knowledge. This is not unreasonable, as much of this stock is public information, and even proprietary information can be accessed through licensing agreements or foreign direct investment. The technology component is further assumed to increase exogenously through time, reflecting the global pace of technological innovation. The efficiency component, on the other hand, is not common across countries, and will vary between 0 and 100 percent-an efficiency level that is less than 100 percent implies that a country is operating inside its production possibilities frontier. In this framework, therefore, differences in country-level TFP primarily reflect differences in efficiency. 


\section{B. Previous Literature}

There is a large and growing literature that documents the importance of good institutions for growth and income over the long run (Acemoglu, Johnson, and Robinson, 2000; Hall and Jones, 1999; Engerman and Sokoloff, 1997; and many others).

However, empirical work focusing on the key link between institutions and efficiency is somewhat more recent. Moroney and Lovell (1997) were the first to use stochastic frontier techniques to compare the performances of Organization of Economic Cooperation and Development (OECD) members and planned economies over the period 1978-80, with the objective of quantifying the extent to which market economies were more efficient than the planned economies of Eastern Europe. Adkins, Moomaw, and Savides (2002) extend this stochastic-frontier approach by examining the sources of inefficiency across 75 countries and focusing on the role of economic and political institutions. Similarly, Kneller and Stevens (2002) take a panel of 82 countries and examine the impact on efficiency of geography, trade, and various measures of government policy. This paper goes further by considering a longer data set with a broader set of countries and examining the specific implications for Ukraine.

\section{EMPIRICAL ANALYSIS}

\section{A. The Model}

In line with the stochastic-frontier approach, a country's output can be expressed as the product of two components:

$$
\text { Output }=\text { Efficiency } \times \text { Optimal Production }
$$

The level of optimal production incorporates the latest globally available technology, and reflects the amount of output that a country could produce if it were to use its resources optimally, employing world-class, best-practice techniques. Again, we assume for the moment that all countries have equal access to this technology. Countries differ in their overall productivity, however, through the efficiency term - which is a fraction between 0 and 1. If a country is operating at an efficiency level of 100 percent (efficiency $=1$ ), then it is using all its available inputs in the most productive manner possible, given the current state of worldwide technology. A level below 100 percent represents a situation in which local frictions cause the country to produce a point within the best-practice frontier.

Formally, the optimal level of output is represented by the (common) production function $f\left(\mathbf{Z}_{i t}\right)$. Each country's actual output $(Y)$, therefore, can be expressed as a function of the production technology

$$
Y_{i t}=f\left(\mathbf{Z}_{i t}\right) \xi_{i} \exp \left(v_{i t}\right)
$$


where $i$ and $t$ are country and time indices, respectively, and $\mathbf{Z}$ represents the country's factors of production.

The level of efficiency is represented by $\xi$, which falls into the range $(0<\xi \leq 1)$. The stochastic error term, $v_{i t}$, reflects the random character of the frontier, owing to statistical noise, measurement error, or other effects not captured by the model. The model recognizes that countries may differ in their overall productivity through the term $\xi$. Again, if a country is 100 percent efficient $(\xi=1)$, it is using all available inputs in the most productive manner.

Taking logs, the model can be rewritten as:

$$
\log \left(Y_{i t}\right)=\log \left[f\left(\mathbf{Z}_{i t}\right)\right]+v_{i t}-u_{i t}
$$

where we define the inefficiency term, $u_{i t}=-\log \left(\xi_{i t}\right)$. This term represents the extent to which output falls below the production frontier. The inefficiency and noise terms are

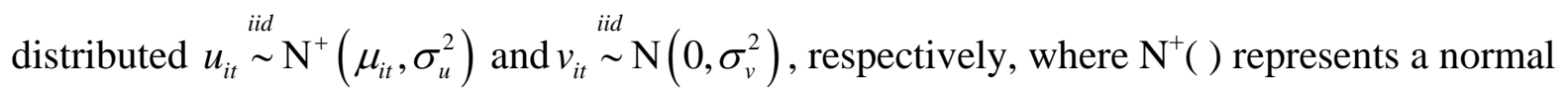
distribution with a truncated left tail at zero. By restricting $u_{i t}$ to a truncated positive normal distribution, we ensure that the efficiency term falls within the range $0<\xi_{i t} \leq 1$.

Also, the mean level of inefficiency $\left(u_{i t}\right)$ is represented by the term $\mu_{i t}$, and is assumed to be a function of the explanatory variables $z_{i t}$, so that:

$$
\mu_{i t}=z_{i t} \delta
$$

In our case, we hope to use an explanatory variable (z) that captures institutional strength. To the extent that an institutional improvement is associated with a reduction in the average level of inefficiency, we expect that $\delta$ will be negative.

Moreover, we allow for heteroskedasticity in the (in)efficiency term by making the variance of $u_{i t}$ a function of the same set of regressors, so that

$$
\sigma_{u}^{2}(\cdot)=\exp \left(z_{i t} \gamma\right)
$$

For the (global) optimal production function, $f\left(\mathbf{Z}_{i t}\right)$, we assume a human-capital augmented Cobb-Douglas specification, as outlined in Hall and Jones (1998):

$$
f\left(\mathbf{Z}_{i t}\right)=A_{0} e^{\eta t} K_{i t}^{\alpha}\left(h_{i t} L_{i t}\right)^{\beta}
$$


where $t$ is a time index, $K$ is the capital stock, $L$ is the labor force, and $h$ is a measure of human capital. In our specification, human capital "multiplies" the effectiveness of the available labor force. We do not assume that $(\alpha+\beta)=1$, and so allow for the possibility of nonconstant returns to scale. However, we do assume a steady rate of global technical progress, $\eta$.

The assumption that all countries have equal access to a common technology was perhaps violated for Eastern bloc countries during the cold war. During this period, there were numerous legal prohibitions preventing the free flow of technology between East and West. Indeed, in the 1990s part of the early optimism regarding the transition economies stemmed from an expectation that, given their rich factor endowments, a sudden inflow of new Western technology would produce a clear and rapid increase in output. To allow for this possibility, the constant term $A_{0}$ is permitted to take a different value for transition countries prior to the fall of the Berlin wall.

Rearranging and taking logs, we get

$$
\log \frac{f\left(\mathbf{Z}_{i t}\right)}{L_{i t}}=\text { constant }+\alpha k_{i t}+\beta h_{i t}-(1-\alpha-\beta) L_{i t}+\eta t
$$

where $k$ is a measure of (log) capital per worker. Defining $y$ as (log) output per worker, we then have a regression model:

$$
y_{i t}=c_{0}+c_{1} d+c_{2} k_{i t}+c_{3} h_{i t}+c_{4} L_{i t}+c_{5} t+v_{i t}-u_{i t}
$$

In this specification, $d$ is a Cold-War dummy variable for transition countries, $c_{2}=\alpha, c_{3}=\beta, c_{4}=-(1-\alpha-\beta)$, and $c_{5}=\eta$. If $c_{4}<0$, there is evidence suggesting decreasing returns to scale.

\section{B. Econometric Considerations}

The key goal of this paper is to account for cross-country differences in efficiency. A number of previous studies, in considering the determinants of efficiency, have used a two-step approach - estimating the production frontier in the first step, and then using the resulting efficiency estimates in a second-stage regression to determine the impact of the variables under study $(z){ }^{2}$

\footnotetext{
${ }^{2}$ For example, see Pitt and Lee (1981), and Kalirajan (1981).
} 
Unfortunately, there are a number of problems with a two-step approach. ${ }^{3}$ The main concern is that, if the $z$ variables are correlated with the production-function inputs $\mathbf{Z}$, the first-stage regression will suffer from an omitted-variables problem. For example, suppose the model is true and $z$ is positively correlated with efficiency $(\xi)$. If efficiency is also positively correlated with some of the inputs (such as human capital), then the estimated frontier coefficients will be biased upward - other things being equal, larger values of $z$ will be associated with higher output levels and higher $\mathbf{Z}$, so that the effect of a particular input will appear to be larger than is actually the case. This will, in turn, affect the residual (and efficiency) estimates for each country, and so will bias the results of the second-stage regression. Additionally, in the presence of heteroskedasticity where the variance of the inefficiency term $\left(\sigma_{u}^{2}\right)$ is related to $z$, the second-stage regression may be biased even further. In this case, the problem is that $u$ is measured with an error that is correlated with $z$, the regressor in the second-step regression. Failing to account for this relationship will result in estimates that are incorrect. ${ }^{4}$

The only way to avoid such issues is to estimate the production frontier and the determinants of efficiency within a single procedure. The results shown below stem from a one-step maximum-likelihood framework, drawing on the methodologies suggested by Battese and Coelli (1995) and extended by Wang and Schmidt (2002). A two-step estimation is also included for comparison.

\section{Data}

Data on inputs and output are taken from a recent cross-country data set provided by Baier, Dwyer, and Tamura (2004). The authors combine and extend the Penn World Tables (6.1) and the Barro and Lee human-capital data set (1993) to a produce a panel of 145 countries, accounting for 98 percent of the world population.

Real output per worker $(y)$ is measured in 1985 U.S. dollars, using purchasing-power parity (PPP) exchange rates. The adjustment for changes in PPP and prices ensures that the observations are comparable across countries and across time. Real capital per worker $(k)$ is also in 1985 dollars, where the capital stock is estimated using the perpetual inventory method - these estimates in turn are derived from PPP-adjusted investment rates and assume a depreciation rate of 7 percent. The data include a broad measure of human capital $(h)$, which not only measures the average education of the workforce, but also takes into account the average level of workplace experience. ${ }^{5}$

\footnotetext{
${ }^{3}$ See the discussion in Kumbahar and Lovell (2000).

${ }^{4}$ See the discussion in Wang and Schmidt (2002).

${ }^{5}$ Using a more narrow measure of human capital, which only considers average education, does not materially change our results.
} 
To investigate the impact of institutions on efficiency, we use the institution-based indices provided in the World Bank's cross-country governance data set, as developed and presented in Kaufman, Kray, and Mastruzzi (2005). This data set covers a broad range of countries and provides various country-level measures of institutional strength - the measures are drawn from a combination of expert polls and business surveys. Using individual survey/poll results, the World Bank authors use an unobserved-components technique to recover an index of five underlying institutional concepts. The areas include:

- $\quad$ Rule of Law, which captures the extent to which fair and predictable rules form the basis for economic and social interactions and the extent to which property rights are protected.

- $\quad$ Political stability, which assesses the perception that government power may be destabilized or overthrown by unconstitutional or violent means.

- $\quad$ Control of corruption, which measures perceptions of corruption, defined as the use of public power for private gain.

- Government effectiveness, which estimates the quality of public service provision, the quality of the bureaucracy, the competence of civil servants, the independence of the civil service, and the government's credibility in committing to its policies.

- $\quad$ And regulatory quality, which gauges the incidence of market-unfriendly policies such as price controls or poor bank supervision, as well as the burden of excessive regulation.

Each of these indicators is distributed normally, with a mean of zero and a standard deviation of one. This implies that virtually all scores lie between -2.5 and 2.5, with higher scores corresponding to "better" outcomes. The measures are strongly correlated, and so distinguishing the separate impact of any single concept is problematic. Therefore, we define a sixth summary index of "institutional strength," derived from a principal-components decomposition of the five indices outlined above.

\section{RESUlts}

The regression includes data from 1950-2000, and covers 128 countries (excluding members of OPEC). Following usual practice, the capital share of output is constrained to correspond to actual national-accounts data, so that $\alpha=0.35 .^{6}$

\footnotetext{
${ }^{6}$ In a recent paper, Aiyar and Dalgaard (2005) show that, for the purposes of measuring TFP, assuming a CobbDouglas production function with identical capital shares across countries serves as an accurate approximation.
} 
The rate of global technological progress is determined exogenously. Looking at the data, the panel is somewhat unbalanced, with more and more countries included in the later observations. The countries with a longer set of observations tend to be relatively welldeveloped and wealthy, whereas those with only a few recent observations tend to be less well off. This complicates estimation of the global pace of technological improvement, as the progressive addition of poorer and poorer countries will lead to the appearance of a negative rate of growth. To address this issue, we first estimate the technological growth rate for the subset of OECD countries. We then assume that this value is the rate of growth for the global (best-practice) frontier, and constrain our model accordingly. The results suggest a pace of technological improvement of about 0.5 percent per year, broadly comparable to the 0.8 percent estimate provided by Weil (2005). The model is estimated via maximum likelihood.

The results from this approach are indistinguishable from those that are based on a more complex production function with heterogeneous capital shares. This result mirrors a similar conclusion in Hall and Jones (1996). 


\section{Table 1. Estimation Results}

Maximum-Likelihood Estimates of the Global Production Frontier and Determinants of Technical Efficiency, 1950-2000

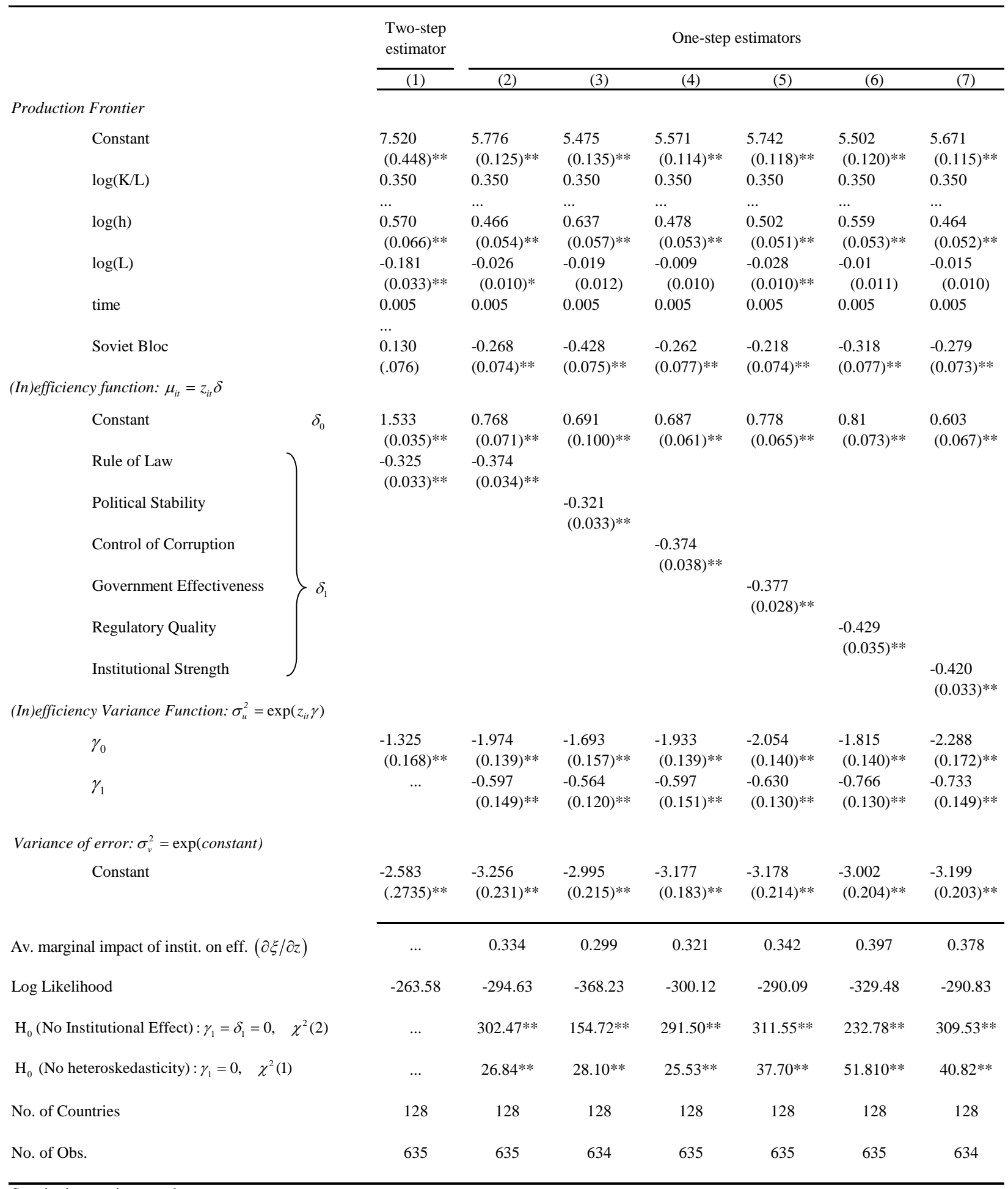

Standard errors in parentheses

* significant at $10 \%$; ** significant at $5 \%$.

Source: IMF staff estimates. 
The coefficients are broadly in line with expectations, with the correct sign. The estimated elasticity of output with respect to labor $(\beta)$ ranges from 0.47 to 0.64 , providing some evidence of (mild) global decreasing returns to scale. This is confirmed by the fact that the estimate of $-(1-\alpha-\beta)$ is universally less than zero, although it is not always significant. The coefficient on the Soviet bloc dummy is negative and significant-again the dummy allows for the possibility that the planned economies of Eastern Europe had only limited access to Western technology prior to 1990. The results suggest that, during the cold war, the bestpractice technology available to these countries was about 20-35 percent less productive than the technology available to the rest of the world; and given the characteristics of central planning within the Eastern bloc, many of these countries would have been operating well within this (reduced) frontier. The finding is broadly consistent with the results of Moroney and Lovell (1997) who conclude that, over 1978-80, the planned economies were at least 25 percent less efficient than the market economies of the West.

Looking at the determinants of efficiency, the institutional coefficients are uniformly significant; the negative values reflect the fact that an increase in institutional strength is associated with a decrease in the inefficiency term $u$. Measuring the quantitative impact of better institutions, the table provides an estimate of the average marginal impact of institutional strength on efficiency. To illustrate, if we look at column (7), the results suggest that a one standard-deviation improvement in the institutional index is associated with a 38 percent improvement in the efficiency ratio-i.e., an efficiency ratio of 0.50 would increase to about $0.69 .{ }^{7}$ Specific calculations for Ukraine are covered in more detail below.

The two-step estimator seems different from the single-step estimator, and suggests that the two-step frontier parameters may indeed be biased upward, as expected. However, this impact does not appear overly important.

Likelihood-ratio tests all support the chosen specification. The tests uniformly suggest the importance of (i) modeling inefficiency as a function of the institutional variable, and (ii) allowing for heteroskedasticity.

Figure 1 below provides an illustration of our preferred model, corresponding to column (7). The independent institutional variable is the summary index of institutional strength, and the frontier is calculated using Ukraine's level of labor and human capital. As shown, the results suggest that Ukraine is operating significantly below potential.

\footnotetext{
${ }^{7}$ This is a lower bound, given the curvature of the efficiency function and the fact that a one-standard deviation movement in the institutional variable represents a substantial change.
} 


\section{Figure 1. The Global Best-Practice Frontier}

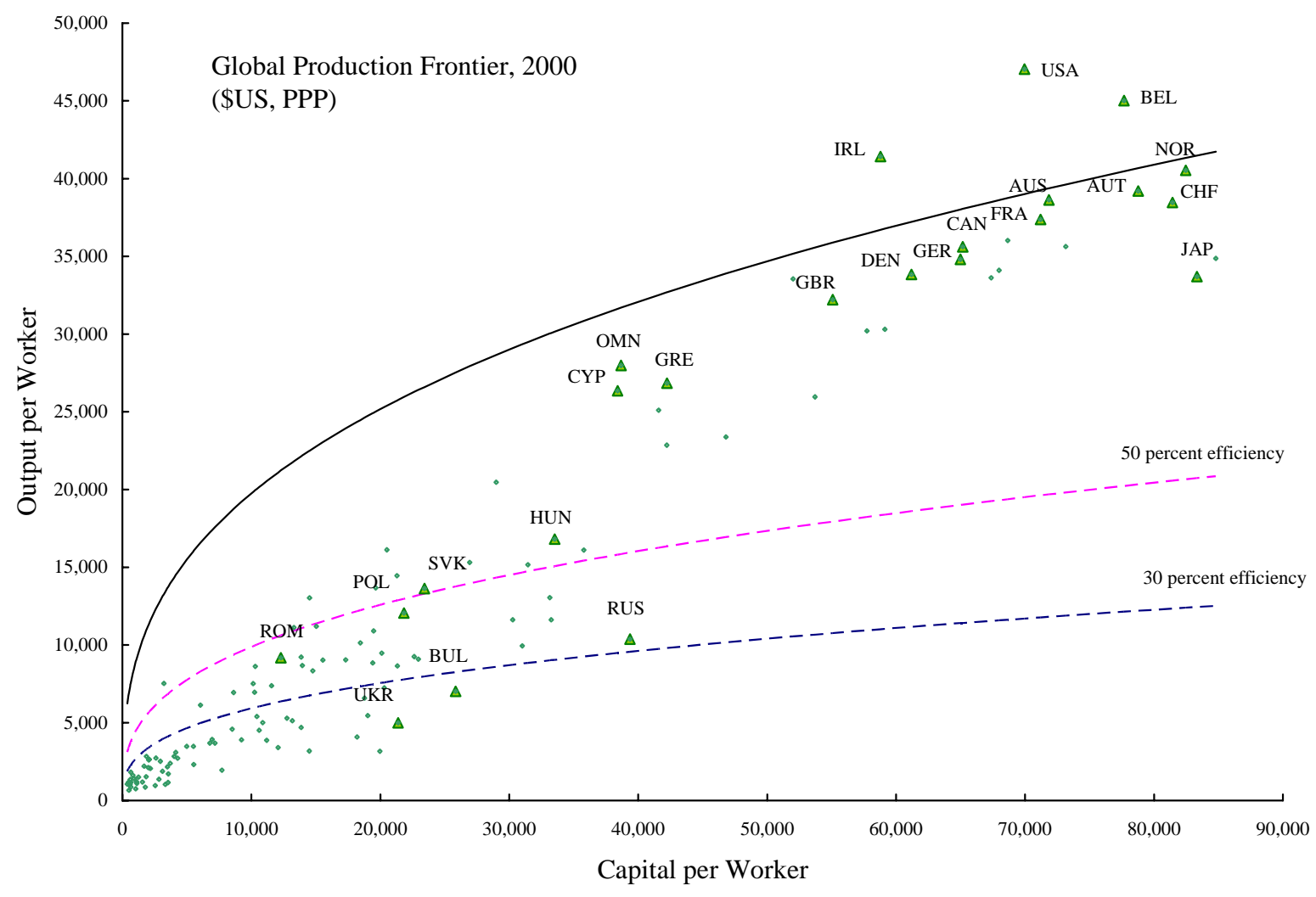

Using the same model to provide individual estimates of country-specific efficiency $(\xi)$, the regional averages for 1990-2000 are as shown below. The average value for Ukraine over the same period was estimated at 29.3 percent. $^{8}$

Table 2. Efficiency Estimates

\begin{tabular}{lllc}
\hline & $\underline{1990}$ & $\underline{2000}$ & $\underline{1990-2000}$ \\
EU-15 & .831 & .852 & .841 \\
Accession Countries & .580 & .541 & .560 \\
Candidate Countries & .486 & .418 & .454 \\
Commonwealth and & .464 & .233 & .343 \\
Independent States (CIS) & & & \\
Ukraine & .485 & .220 & .293 \\
Worldwide & .636 & .549 & .592 \\
\hline
\end{tabular}

Source: IMF staff estimates.

\footnotetext{
${ }^{8}$ The level of efficiency is estimated as $\xi_{i}=E\left[\exp \left(-u_{i}\right) \mid \varepsilon_{i t}\right]$ where $\varepsilon_{i t}=\left(v_{i t}-u_{i}\right)$ is the observed regression error. See Appendix I.
} 
To illustrate the impact of institutions, Figure 2 is also derived from the model in column (7), and shows the relationship between our summary institutional index and efficiency. In the case of Ukraine, the economy's low level of efficiency seems clearly associated with its weak institutional base.

Figure 2. The Impact of Institutional Strength

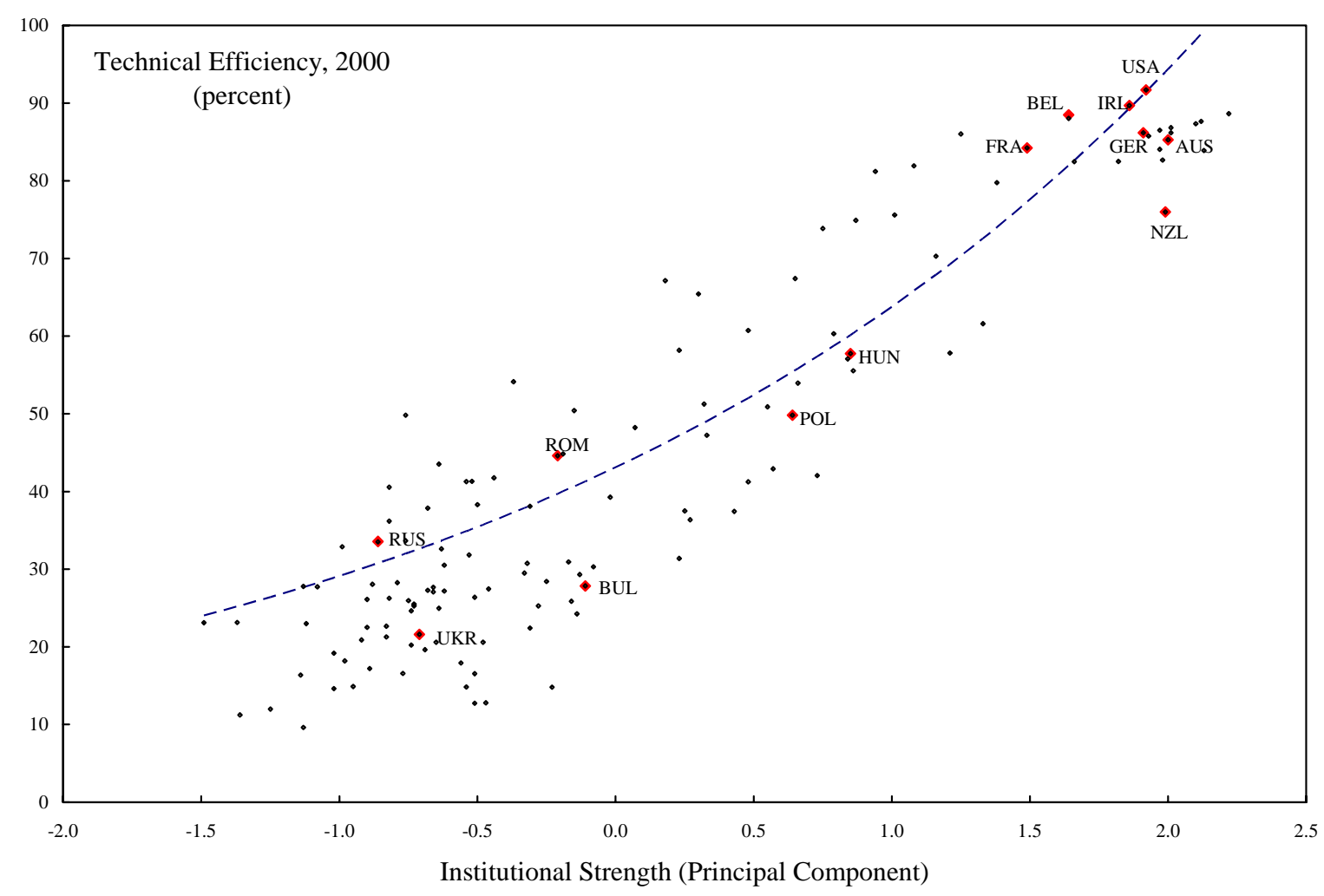

\section{IMPLICATIONS AND DISCUSSION}

Ukraine displayed a significant fall in efficiency over the 1990s-falling from about 49 percent to 22 percent between 1990 and 2000 (see Figure 3). In part, this fall reflects the changing nature of the best-practice frontier. In 1990, the technology available to Ukraine and other Eastern bloc countries was constrained by cold-war considerations, and so Ukraine faced a lower best-practice frontier compared to the rest of the world. When estimating efficiency during this period, therefore, Ukraine (and most other planned economies) are measured against a lower benchmark and so appear relatively less inefficient. By 2000, however, the latest Western technology was equally available to all countries, including those in Eastern Europe and the former Soviet Union. Over the 1990s, therefore, these countries faced an inflow of new ideas and techniques and enjoyed a dramatically accelerated pace of technological growth, represented by a rapid shift outward of the frontier. In this situation, even countries with a steady level of output per worker will appear to have become less efficient, as in effect they will have failed to take advantage of a new and broad range of post-cold war opportunities. 
For the most part, those countries that were not part of the Soviet Union appear to have been able to capitalize on a rapid influx of new technology, posting significant gains in output per worker and broadly maintaining their overall level of efficiency. For countries such as Romania and Poland, these gains resulted primarily from increases in efficiency rather than factor accumulation, as represented by a vertical upward movement toward the frontier (although in the case of Poland, the net vertical movement conceals a investment collapse and subsequent boom during the 1990s). For countries such as Slovakia and Hungary, output gains were the result of improved efficiency combined with significant increases in capital stocks - which in turn reflected dramatic inward flows of foreign direct investment.

Figure 3. Transition and Efficiency During the 1990s

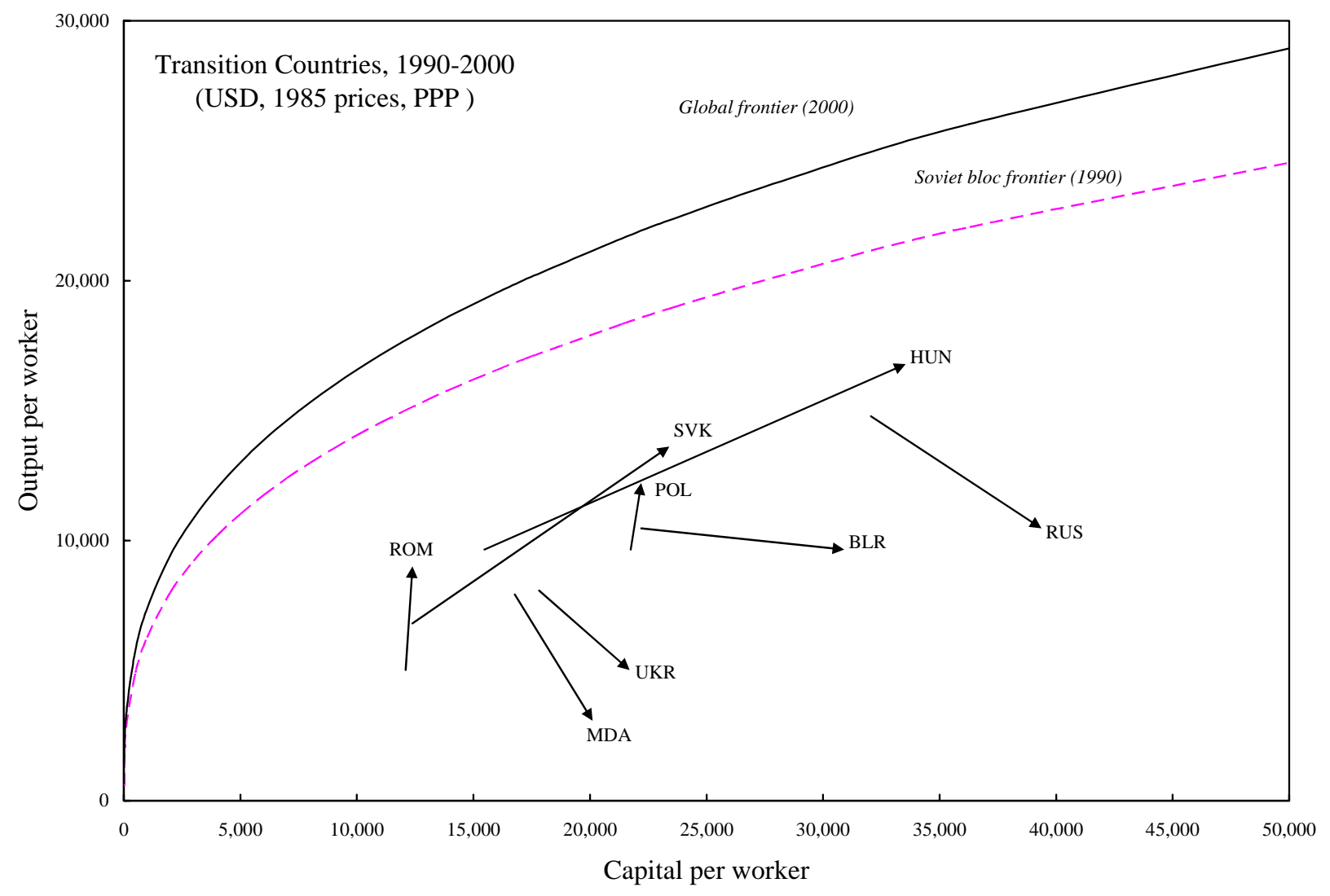

In contrast, CIS countries do not seem to have dealt as well with the sudden exposure to Western techniques in the 1990s. Instead, production in these countries appears to have continued in the same old manner and has shown little improvement. However, this only partly explains Ukraine’s falling efficiency. Rather than maintain a steady level of output, Ukraine and other CIS countries actually experienced a serious and sustained contraction in 
output over the 1990s, despite significant capital investment. The causes of this output fall throughout the former Soviet Union have been studied extensively elsewhere, ${ }^{9}$ and reflect in large part the dismantling of the Soviet state's central-planning apparatus. In contrast to other countries in Eastern Europe, these institutions were not replaced. Rather than moving to a more market-oriented system, the new states of the CIS found themselves in an institutional vacuum - and rather than an environment that encouraged innovative and productive activity, they faced instead a surge in uncertainty and rent-seeking behavior. The example of Belarus is an interesting case in point. As can be seen in Figure 3, that country's output contraction was comparatively mild. A potential explanation may lie in the fact that, unlike most other CIS countries, Belarus had considerably more success in maintaining the economy's old Soviet-style institutions and so managed to avoid the institutional vacuum experienced by its neighbors. Consequently, while Belarus failed to benefit from the new technological opportunities offered from the West, it nonetheless managed to avoid the sharp recessions experienced by other CIS countries. This approach may have shielded the population from the worst of the 1990s, but as outlined below, institutional stagnation is unlikely to be a recipe for enduring success in the future.

Output in Ukraine has grown rapidly since 2000, owing mostly to greater efficiency, rather than investment. As shown in Figure 4 below, the nadir of Ukraine's output contraction occurred in 2000. Since then the economy has generally grown strongly, often surpassing local and international forecasts. The causes of the recovery are outlined in Berengaut and others (2002), and reflect a complex combination of factors, including a huge boost in competitiveness following the financial crisis of 1998, the availability of significant excess capacity, and a recovery in neighboring Russia. In addition, however, Ukraine's turnaround also reflected the impact of first-generation structural reforms introduced in 1999-2000. ${ }^{10}$ These reforms focused initially on the energy sector and were key in reducing the prevalence of barter payments and arrears. Addressing Ukraine's nonpayment culture in turn helped foster a more efficient allocation of resources and the beginnings of a working financial system. In terms of our model, efficiency in Ukraine increased from 22 percent in 2000 to about 30 percent in 2005.

\footnotetext{
${ }^{9}$ See Berengaut and Elborgh-Woytek (2005).

${ }^{10}$ The year 2000 is identified as an "institutional transition” in IMF (2005).
} 
Figure 4. Ukraine: Alternative Scenarios

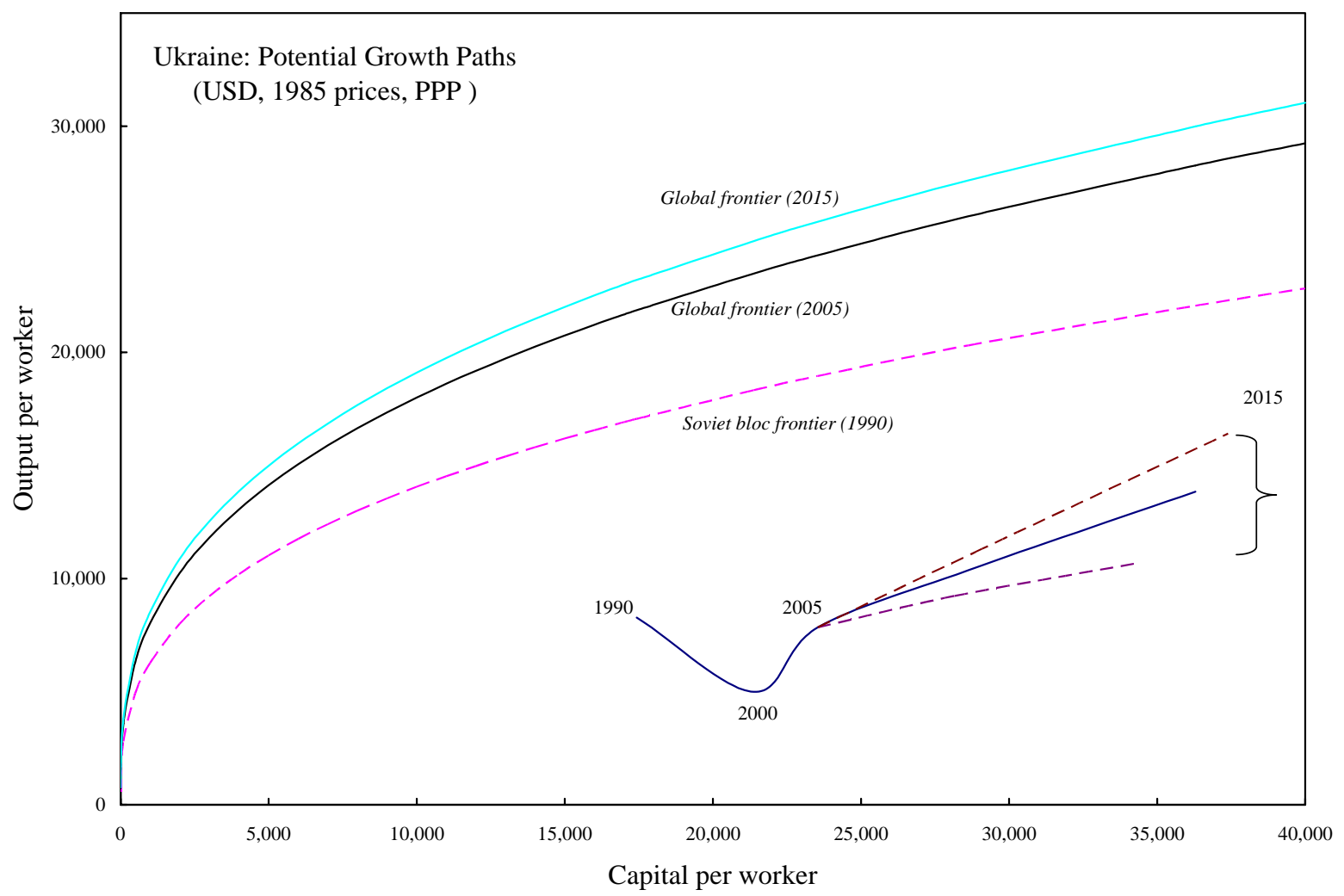

From the experience of 2005, however, it appears that Ukraine's impressive output performance has started to wane. With a less favorable external environment, with capacity bottlenecks emerging in a number of sectors, with investor uncertainty, and with minimal structural reform over the past few years, the economy is now entering a more modest growth phase. This in itself is not surprising, as the remarkable rates of the past couple of years were most likely unsustainable. However, the challenge now facing the authorities is how to best secure a robust and sustainable improvement in the immediate future.

Looking forward, our results suggest that lasting improvements in living standards will depend more on the authorities' ability to increase Ukraine's efficiency rather than on higher rates of capital accumulation. This in turn will require a sustained commitment to improved market-oriented institutions and a renewed effort to push forward long-delayed structural reforms. The October 2005 World Economic Outlook highlights the importance of institutions for growth and notes that, while institutions reflect specific historical developments and tend to be persistent, they are not immutable. In this context, the World Economic Outlook finds that external anchors have often helped foster institutional change and that, for transition countries, the prospect of EU accession stands as a classic example of a successful anchor. 
In this light, the reform agenda outlined by the authorities, which is mostly anchored within the EU-Ukraine Action plan, is both timely and appropriate. The Action Plan covers a wide range of tasks and measures, and by harmonizing Ukrainian standards with those of the EU, it aims to accelerate Ukraine's progress toward a market-based economy that is firmly integrated within Europe and global markets (Table 4). The potential benefits of an EU-based strategy have been discussed in depth by a number of different commentators (see Havryshylyn, Lissovolik, and Shadman-Valavi, 2000), and should start to accrue well in advance of any formal accession date. In order to gauge the impact of such an effort, we outline a range of reform scenarios below.

An EU-centered series of institutional reforms could materially boost Ukraine's sustainable growth rates. The IMF staff's current baseline scenario, which envisages a medium-term annual growth rate of about 5 percent, assumes a moderately successful reform effort. Using the estimated model above, this scenario is consistent with a mild improvement in Ukraine's institutions, so that the economy's overall efficiency level rises from 30 percent to 46 percent over 2005-15. In effect, the scenario assumes that by 2015, Ukraine will have the institutional quality enjoyed by current EU candidate countries such as Romania. Starting from this baseline, it is also possible to project a "low-case" scenario detailing the consequences of an ineffective or incomplete reform effort. If the authorities fail to improve Ukraine's institutional base, so that efficiency levels improve only slightly over the next decade, then the economy may face an average growth rate as low as 2 percent per year. In general terms, this corresponds to the low-case growth scenario illustrated in a previous IMF staff report for Ukraine. ${ }^{11}$

Table 3. Contributions to Long-Term Growth, 2005-15

\begin{tabular}{lccc}
\hline \multicolumn{1}{c}{ Efficiency } & $\begin{array}{c}\text { Low case } \\
30 \text { to } 36\end{array}$ & $\begin{array}{c}\text { Baseline } \\
30 \text { to } 46\end{array}$ & $\begin{array}{c}\text { High case } \\
30 \text { to } 60\end{array}$ \\
\cline { 2 - 4 } Capital per worker & 1.2 & 1.7 & 2.1 \\
Human capital & 0.1 & 0.1 & 0.1 \\
TFP & 1.7 & 4.2 & 7.3 \\
$\quad$ o/w Tech. progress & 0.5 & 0.5 & 0.5 \\
o/w Efficiency & 1.2 & 3.8 & 6.8 \\
Output per worker & 3.0 & 6.0 & 9.5 \\
& & & \\
Memo item & & & \\
Real growth rate & 2.0 & 5.0 & 8.5 \\
\hline
\end{tabular}

Source: IMF staff calculations.

11 “Long-Term Growth Prospects,” Ukraine: Selected Issues, April 2003. 
Full implementation of the authorities’ EU-centered agenda represents a high-case growth scenario. In this scenario, it is assumed that by 2015, Ukraine will have harmonized its internal regulations and standards sufficiently so that it will have met all the chief requirements for EU membership. To this end, the scenario assumes that, after 10 years, Ukraine will have the institutional quality and efficiency currently enjoyed by recent accession countries such as Poland and Hungary. This corresponds to an increase in efficiency from 30 percent to about 60 percent, which in turn implies an average annual growth rate of about 8.5 percent over the coming decade.

\section{Table 4. Key Aspects of the Ukraine-EU Action Plan}

Legal framework and governance

- $\quad$ Adopt Joint Stock Company Law

- $\quad$ Improve the competence and independence of auditors

- $\quad$ Implement effectively competition and bankruptcy legislation

- $\quad$ Eliminate inconsistencies in the existing Economic and Civil Codes

- $\quad$ Adopt legislation necessary for implementing new Land Code; remove current restrictions in Land Code on nonagricultural land ownership

- $\quad$ Complete and implement reform of the court system to ensure independence, impartiality, and efficiency of the judiciary

- $\quad$ Promote transparency and accountability in the public administration, particularly concerning the reform of the civil service based on European standards

- $\quad$ Adopt a definition of state aid compatible with the EU, increase transparency of state aid, and prohibit state that distorts trade between Ukraine and the EU

\section{Fiscal reforms}

- $\quad$ Reinforce fiscal sustainability, including by taking measures to address medium-term trends in the pension system

- $\quad$ Implement comprehensive strategic plan for State Tax Administration

- $\quad$ Adopt Customs Code in line with WTO agreements and EU legislation

- $\quad$ Solve issue of VAT refund backlog

- $\quad$ Improve transparency of public finance management

- $\quad$ Continue approximation to EU legislation on public procurement

\section{Energy sector}

- $\quad$ Adopt law to strengthen operation of National Electricity Regulatory Commission

- $\quad$ Develop gas sector restructuring plan

- $\quad$ Implement Ukraine’s coal mine restructuring plan

- $\quad$ Ensure convergence of energy price developments in Ukrainian and EU markets

Financial sector

- $\quad$ Strengthen independence of NBU by bringing NBU law in line with EU standards.

- $\quad$ Comply with the IMF's FSAP of November 2003

- $\quad$ Develop domestic securities market

Source: Cabinet of Ministers, March 2005. 


\section{Caveats}

A first concern with the above exercise is the possibility that, rather than measuring the impact of better institutions on higher per capita income, we are capturing instead the reverse effect of higher income on better institutions. While such reverse causation is theoretically possible, it has little empirical support. This is still an area of ongoing research, but in general, attempts to separate the two effects have generally confirmed the existence of a strong, robust, positive causal relationship from institutions to income. In contrast, however, they have found that the feedback relationship from income to institutions is extremely weak, or even negative (Kaufmann, 2002).

Another possible concern is that the variables under study are often poorly measured, particularly when considering cross-country indicators of institutional strength or capital stocks. Again, this is a possibility, but the relationship between institutions and productivity is compelling a priori and has been demonstrated empirically time and again using a wide variety of institutional indicators and capital-stock estimates.

A more plausible worry, however, is that such measurement issues are particularly acute in the case of the transition countries. It is almost certainly true that investment was overstated under the communist central-planning system, and that a portion of the measured capital stock of socialist countries was so poorly maintained and obsolescent as to be effectively useless. This would bias our estimates for these countries, leading us to underestimate their actual levels of efficiency. It is difficult to know just how much weight to give to this consideration, but a possible guide might be contained within the cold-war dummy variable. In our model, it is estimated that, during the cold war, the existence of binding technology constraints meant that socialist countries were about 20-35 percent less productive than their counterparts in the West. If, instead, we were to assume that these countries had access to the same technology as the rest of the world, then the cold-war dummy would provide a rough approximation of the actual factor endowments of these countries-i.e. it would suggest that 20-35 percent of capital in these countries was nonexistent in any real sense.

A related concern is the possibility that the results for Ukraine, and other transition countries, may have been influenced by their large and poorly measured informal sectors. In the case of Ukraine, the shadow economy is estimated to have grown significantly during the early 1990s, with the result that output and growth for those years will have been substantially under reported. Again, this would lead us to exaggerate the collapse in output and efficiency in the 1990s, and perhaps to underestimate the level of efficiency. This is almost certainly one aspect of the link between institutions and efficiency, as it has often been noted that shadow economies are less important in those countries where government institutions are strong. And there is reason to believe that this aspect has played an important part in Ukraine's efficiency gains since 2000 — it is estimated that, after rising during the early 1990s, the shadow economy's size peaked in 1997 as a proportion of GDP and has been 
falling ever since. However, this possibility raises a worrying concern. If reforms were to stall in Ukraine, economic activity might once again return into the shadows, which would then bring the observed annual growth rate below even the low-case projection of 2 percent. The presence of a large and active informal sector in Ukraine, therefore, may increase the downside risks of further institutional stagnation.

\section{Conclusions}

Ukraine has the potential to be a very wealthy country. Ukraine has some of the best agricultural land in the world, an enviable supply of hydrocarbons and minerals, and a relatively well-developed infrastructure. Literacy is close to 100 percent, and the labor force is educated to the highest technical and scientific levels (World Bank, 2000). Despite these advantages, however, Ukraine's per capita income remains low.

This paper has argued that Ukraine's failure to tap its full potential is mainly a result of its market-unfriendly institutional base. Having inherited a Soviet framework that was ill suited to the needs of a market economy, Ukraine has been slow in establishing the marketenhancing institutions needed to use its resources efficiently.

The authorities appear to be poised to tackle this issue, and have articulated a wide-ranging reform program. This program has been anchored within a broader strategy of greater integration with the EU and global markets.

In quantifying the benefits of market-friendly institutional reform, our results suggest that durable growth in Ukraine will depend critically on the authorities' ability to secure the foundations of a modern market economy. Given the size of the gap between Ukraine's current output and its long-term potential, and given the experience of other countries, the results indicate that a successful effort might boost Ukraine's long-run growth rate to about 8.5 percent per year. By raising the efficiency with which Ukraine uses its already-substantial resource base, this implies that continuing reform might allow a doubling of per capita income within a decade-such a performance would be remarkable, and would place Ukraine alongside recent "growth miracle" countries. 


\section{Estimating Efficiency ${ }^{1}$}

The stochastic frontier model can be expressed by

$$
y_{i t}=x_{i t} \beta+\varepsilon_{i t}
$$

Where

$$
\varepsilon_{i t}=\left(v_{i t}-u_{i t}\right)=y_{i t}-x_{i t} \beta
$$

We want to estimate the level of technical efficiency, $\xi_{i t}=\exp \left(-u_{i t}\right)$. However, we only observe $\varepsilon_{i t}$, so first we need to find an expression for the conditional expectation $E\left[\exp \left(-u_{i t}\right) \mid \varepsilon_{i t}\right]$. The density function for $v_{i t}$ is the normal $N\left(0, \sigma_{v}{ }^{2}\right)$, whereas the truncated normal density for $u_{i t}$ is expressed as

$$
f_{u}(u)=\left[\sqrt{2 \pi} \sigma_{u} \Phi\left(\frac{z \delta}{\sigma_{u}}\right)\right]^{-1} \exp \left[-\frac{(u-z \delta)^{2}}{2 \sigma_{u}^{2}}\right], \quad u \geq 0
$$

Subscripts $i$ and $t$ have been omitted for convenience of presentation, and $\Phi($ ) represents the standard normal distribution function. Therefore, the joint density function for $\varepsilon_{i t}$ and $u_{i t}$ is

$$
f_{\varepsilon, u}(\varepsilon, u)=\left[2 \pi \sigma_{u} \sigma_{v} \Phi\left(\frac{z \delta}{\sigma_{u}}\right)\right]^{-1} \exp \left[-\frac{1}{2} \frac{\left(u-\mu_{*}\right)^{2}}{\sigma_{*}^{2}}+\frac{(\varepsilon+z \delta)^{2}}{\left(\sigma_{v}^{2}+\sigma_{u}^{2}\right)}\right], \quad u \geq 0,
$$

Where

$$
\begin{gathered}
\mu_{*}=\frac{\sigma_{v}^{2} z \delta-\sigma_{u}^{2} \varepsilon}{\sigma_{v}^{2}+\sigma_{u}{ }^{2}}=(1-\gamma) z \delta-\gamma \varepsilon \text { and } \sigma_{*}^{2}=\frac{\sigma_{v}{ }^{2} \sigma_{u}{ }^{2}}{\left(\sigma_{v}{ }^{2}+\sigma_{u}{ }^{2}\right)}=\gamma(1-\gamma) \sigma_{s}{ }^{2} \\
\sigma_{s}{ }^{2} \equiv \sigma_{v}{ }^{2}+\sigma_{u}{ }^{2} \text { and } \gamma \equiv \sigma_{u}{ }^{2} / \sigma_{s}{ }^{2}
\end{gathered}
$$

It can be shown that, given $\varepsilon_{i t}$, the conditional expectation of a country's efficiency, $\xi_{i t}=\exp \left(-u_{i t}\right)$, is provided by the expression

$$
E[\exp (-u) \mid \varepsilon]=\exp \left(-\mu_{*}+\frac{1}{2} \sigma_{*}^{2}\right)\left[\Phi\left(\frac{\mu_{*}}{\sigma_{*}}-\sigma_{*}\right)\right]\left[\Phi\left(\frac{\mu_{*}}{\sigma_{*}}\right)\right]^{-1}
$$

\footnotetext{
${ }^{1}$ (Battese \& Coelli, 1995)
} 


\section{REFERENCES}

Acemoglu, Daron, Simon Johnson, and James A. Robinson, 2001, “The Colonial Origins of Comparative Development: An Empirical Investigation,” American Economic Review, Vol. 91, No. 5, pp 1369-1401.

Aigner, D.J., C.A.K. Lovell, and P. Schmidt, 1977, “Formulation and Estimation of Stochastic Frontier Production Models,” Journal of Econometrics, Vol. 6, pp. 21-37.

Aiyar, Shekhar, and Carl-Johan Dalgaard, 2004, “Total Factor Productivity Revisited: A Dual Approach to Development Accounting,” Staff Papers, International Monetary Fund, Vol. 52, No.1, pp. 82-102.

Åslund, Anders, 2001, "Building Capitalism: Lessons of the Postcommunist Experience,” Policy Brief No. 10 (Washington: Carnegie Endowment for International Peace).

Baier, Scott L., Gerald P. Dwyer, Jr., and Robert Tamura, 2004, "How Important Are Capital and Total Factor Productivity for Economic Growth?” Working Paper 2004-2a, (Atlanta: Federal Reserve Bank of Atlanta).

Barro, Robert J., and Jong-Wha Lee, 1993, “International Comparisons of Educational Attainment,” NBER Working Papers 4349, (Cambridge, Massachusetts: National Bureau of Economic Research).

Battese, G.E., and T. J. Coelli, 1995, “A Model for Technical Inefficiency Effects in a Stochastic Frontier Production Function for Panel Data,” Empirical Economics, Vol. 20, pp. 325-332.

Berengaut, Julian, and others, 2002, “An Interim Assessment of Ukrainian Output Developments, 2000-01,” IMF Working Paper 02/97 (Washington: International Monetary Fund).

Berengaut, Julian, and Katrin Elborgh-Woytek, 2005, “Who Is Still Haunted by the Specter of Communism? Explaining Relative Output Contractions Under Transition,” IMF Working Paper 05/68 (Washington: International Monetary Fund).

Engerman, Stanley, and Kenneth Sokoloff, 1997, "Factor Endowments, Institutions, and Differential Paths of Growth among New World Economies,” in ed. by S. Harber, How Latin.America Fell Behind, (Stanford, California: Stanford University Press).

Gonzales, Francisco M., 2005, “Insecure Property Rights and Technological Backwardness,” Economic Journal, Vol. 115 (July), pp. 703-721. 
Hall, Robert E., and Charles I. Jones, 1999, "Why Do Some Countries Produce So Much More Output Per Worker Than Others?” The Quarterly Journal of Economics, Vol. 114, No. 1, pp. 83-116.

— Massachusetts: National Bureau of Economic Research).

Havrylyshyn, Oleh, and Ron van Rooden, 2003, "Institutions Matter in Transition, But So Do Policies,” Comparative Economic Studies, Vol. 45, No. 1, pp. 2-24.

Havrylyshyn, Oleh, Bogdan Lissovolik, and Mohammad Shadman-Valavi, 2002, "Economic Growth in Ukraine: What If Reforms and Economic Recovery Had Started Earlier?” in ed. by Stephan von Cramon-Taubadel and Iryna Akimova, Fostering Sustainable Growth in Ukraine, (Heidelberg: Physica-Verlag), pp. 96-115.

International Monetary Fund, 2005, World Economic Outlook: October 2005 (Washington).

Kalirajan, K.P., 1981, “An Econometric Analysis of Yield Variability in Paddy Production,” Canadian Journal of Agricultural Economics, Vol. 29, pp. 283-94.

Kaufman, Daniel, Aart Kray, and Massimo Mastruzzi, 2005,“Governance Matters IV: Governance Indicators for 1996-2004,” Policy Research Working Paper (Washington: World Bank).

Kaufmann, Daniel, 2002, “Growth Without Governance,” Policy Research Working Paper 2928 (Washington: World Bank).

Kneller, R., and P. Stevens, 2002, “The Role of Efficiency as an Explanation of International Income Differences” National Institute Discussion Paper No. 206, (London: National Institute of Economic and Social Research).

Koop, Gary, Jacek Osiewalski, and Mark Steel, 2000, “A Stochastic Frontier Analysis of Output Level and Growth in Poland and Western Economies,” Economics of Planning, Vol. 33, No. 3, pp. 185-202.

Kumbhakar, Subal V., and C.A. Knox Lovell, 2000, Stochastic Frontier Analysis, (Cambridge: Cambridge University Press).

Lucas, Robert E., Jr, 1993, “Making a Miracle,” Econometrica, Vol. 61, No. 2, pp. 251-72.

McGrattan, Ellen R., and James A. Schmitz, Jr., 1998, "Explaining Cross-Country Income Differences,” Staff Report 250 (Minneapolis: Federal Reserve Bank of Minneapolis). 
Moroney, John, and C.A.K. Lovell, 1997, "The Relative Efficiencies of Market and Planned Economies,” Southern Economic Journal, Vol. 63, No.4, pp. 1084-1093.

Pitt, Mark, and Lung-Fei Lee, 1981, "Measurement and Sources of Technical Inefficiency in the Indonesian Weaving Industry,” Journal of Development Economics, Vol. 9, pp. 43-64.

Parente, Stephen L., and Edward C. Prescott, 2004, “A Unified Theory of the Evolution of International Income Levels,” Staff Report 333 (Minneapolis: Federal Reserve Bank of Minneapolis).

— , 1999, “Monopoly Rights: A Barrier to Riches,” American Economic Review, Vol. 89, No. 5, pp. 1216-1233.

Prescott, Edward C., 1997, “Needed: A Theory of Total Factor Productivity,” Staff Report 242, (Minneapolis: Federal Reserve Bank of Minneapolis).

Wang, Hung-jen, and Peter Schmidt, 2002,“One-Step and Two-Step Estimation of the Effects of Exogenous Variables on Technical Efficiency Levels,” Journal of Productivity Analysis, Vol. 18, No. 2, pp. 129-144.

Weil, David N., 2005, Economic Growth (Boston: Addison-Wesley).

Whittaker, J., C. Guermat, and K. Hadri, 2003, "Estimation of Technical Inefficiency Effects Using Panel Data and Doubly Heteroscedastic Stochastic Production Frontiers,” Empirical Economics, Vol. 28, No. 1, pp. 203-222.

World Bank, 2000. Ukraine: Country Assistance Evaluation, Vol. 1 (Washington). 